Article

\title{
On the Road to Circular Public Procurement: Case, Variations, and Potential Actions in Germany
}

\author{
Simone Wurster ${ }^{1, *}$, Rita Schulze ${ }^{2}$ and Ramona G. Simon ${ }^{2}$ \\ 1 Department of Innovation Economics, Technische Universität Berlin (TU Berlin), 10623 Berlin, Germany \\ 2 DECHEMA e.V., 60486 Frankfurt, Germany; rita.schulze@dechema.de (R.S.); \\ ramona.simon@dechema.de (R.G.S.) \\ * Correspondence: simone.wurster@tu-berlin.de
}

Citation: Wurster, S.; Schulze, R.; Simon, R.G. On the Road to Circular Public Procurement: Case, Variations, and Potential Actions in Germany. Sustainability 2021, 13, 13784. https:/ / doi.org/10.3390/su132413784

Academic Editor: Andrea Appolloni

Received: 30 September 2021

Accepted: 3 December 2021

Published: 14 December 2021

Publisher's Note: MDPI stays neutral with regard to jurisdictional claims in published maps and institutional affiliations.

Copyright: (c) 2021 by the authors. Licensee MDPI, Basel, Switzerland. This article is an open access article distributed under the terms and conditions of the Creative Commons Attribution (CC BY) license (https:/ / creativecommons.org/licenses/by/ $4.0 /)$.

\begin{abstract}
According to the United Nations, the consumption of materials is expected to double between 2020 and 2050. At the same time, annual waste generation is forecast to increase by $70 \%$ by 2050 . The circular economy (CE) addresses this problem. However, many barriers to the further development of the CE exist. This article analyses the situation of public procurement in supporting a sustainable CE for tyres in Germany based on 18 interviews with public procurement professionals directly responsible for the purchase of tyres and four additional expert interviews. Based on the dimensions 'current circular public procurement (CPP) intensity' and 'current CPP opportunities', a classification of tyre procurement situations and barriers to sustainable circular tyre procurement is presented. Strategies to overcome these supply-side and demand-side barriers are specified, resulting in nine recommendations for German policymakers. As a way forward, a detailed concept for a pilot project on tyre CPP is provided. The article also shows how the circular public procurement classification can be used to support sustainability measures in a broader context. Finally, the article's outlook focuses on implications to promote sustainable circular tyre procurement in other countries. It explains different framework conditions and elaborates to what extent additional research is necessary to develop appropriate recommendations for those conditions.
\end{abstract}

Keywords: circular economy; public procurement; sustainability; tyres; regulatory framework; policy recommendations; automotive industry

\section{Introduction}

\subsection{Sustainable Development, Public Procurement, and Specific Product Considerations}

The development of global resource consumption and annual waste generation is expected to increase drastically over the next 30 to 40 years (see [1,2]). Therefore, a change from the prevailing linear economy to a more resource-efficient way of adding value is one of the goals for which the model of the circular economy $(\mathrm{CE})$ provides the framework $[3,4]$.

The CE model is based on the three dimensions of sustainability: environmental quality, economic prosperity, and social equity [3]. With regard to the goal of saving resources across material and product lifecycles and the associated benefits for the environment, society, and economy, the so-called $\mathrm{R}$ framework or R hierarchy is considered a key strategy. The $4 \mathrm{R}$ concept comprises reduction, reuse, recycling, and, finally, recovery. The concept can be refined by adding refuse, remanufacture, and repurpose activities into the structural concept [3]. In order to evaluate the most effective procedures for a specific case, sustainability assessments can be conducted.

The implementation of a CE will cause fundamental transformations in many interconnected areas of our economy and society [4]. While various CE aspects of cars are analysed already—see, e.g., [5] for an overview-the implementation of a fully circular value chain is tricky in the case of tyres, not considering the area of public procurement.

CE-related tyre treatment options were identified by [6]. The options are based on the extended R-framework. According to the principles of the $\mathrm{CE}$, the implementation of the 
CE concept into the tyre value chain addresses all lifecycle stages from design to end of life, and requires the involvement of all relevant stakeholders. Valuable resources are needed for the manufacturing of tyres. The main compounds for the rubber are synthetic rubber, natural rubber, carbon black, silica-based compounds, and additives. During vulcanisation, these compounds are irreversibly crosslinked to a three-dimensional network and the rubber is converted into an elastomer [7]. Fabrics and steel wire are embedded for structure and strength. Natural rubber has been added to the EU's list of critical raw materials [8]. Therefore, research to on how to make tyre value chain more sustainable and circular is ongoing. Industry initiatives and research examine, for instance, alternative sources for natural rubber $[9,10]$ and carbon black [11,12]. Other research topics regarding the sustainability of the tyre value chain include the recovery of carbon black or synthetic fabrics $[13,14]$; the extension of the service life of tyres by tyre maintenance and usage behaviour (e.g., pressure control, driving behaviour) $[15,16]$, the improvement of retreading options [17]; the reduction of fuel consumption by introducing novel tire designs (e.g., EU tyre label); and finally, the preservation of materials in the material cycle through the recycling of EOL-tyres into secondary raw materials for various applications $[5,18,19]$.

Despite these efforts, the potential for intensifying the tyre CE has not yet been exhausted, as many approaches still need to be transferred into practice or could be taken up more widely $[4,17]$. At the same time, the acceptance of the use of new sustainable tyre variants (see, e.g., [20] regarding traditional acceptance problems of retreaded tyres) should be enhanced. In Germany, e.g., around 46 million used passenger car tyres are collected each year [13].

In line with [21], this article regards tyres that comply with one or more of these options and meet at least international working standards as 'sustainable CE tyres'. In this context, specific attention is given to the treatment options remanufacturing via retreading and/or recycling. This article focuses on the potential of policy instruments and strategies for public procurement to promote a sustainable $\mathrm{CE}$ for tyres. Public procurement is the process by which 'public authorities, such as government departments or local authorities, purchase work, goods, or services from companies' [22]. The purchasing power of European public procurement institutions is significant. According to the European Commission, 250,000 public authorities in Europe spend around 14\% of GDP on purchasing services, works, and supplies [22]. The importance of the purchasing decisions made by public procurers implies that a CE-oriented tyre purchasing strategy could significantly impact the demand for sustainable tyres in Europe. This article aims to support the necessary transition process to a $\mathrm{CE}$ by providing specific recommendations, including a concept for a pilot project. In addition, a classification of framework conditions is provided as a foundation for the development of strategies to become more circular and sustainable. This classification can also be used in a broad range of additional application fields as a support tool for sustainability-oriented decision making and benchmarking.

\subsection{Research Gaps and Research Questions}

Circular public procurement is a specific type of green public procurement (GPP) [23]. GPP is defined by [24] as 'a process whereby public authorities seek to procure goods, services and works with a reduced environmental impact throughout their life cycle when compared to goods, services and works with the same primary function that would otherwise be procured'.

Cheng et al. [25] analysed the state of the art of GPP research in detail. They provide an extensive overview of existing literature and future trends as well as a comprehensive GPP model with barriers and support factors. Their article also shows three particular research gaps:

1. The GPP discussion 'has mostly focused so far on the specific impacts of GPP implementation' [25]. Strategies to implement GPP for specific product areas are analysed less frequently. As shown in Section 1.1, sustainable, circular tyres make an interesting study case in this context. 
2. Circular public procurement is underrepresented in GPP research. In this context,

Cheng et al. [25] refer to the environmental impacts of proposed projects, which may include 'recycled material'. Apart from the brief mentioning of one circularity aspect, [25] does not consider any other circularity aspects in-depth, not even in the state of the art.

3. Cheng et al. [25] also provide information on the countries where GPP studies took place. Germany is not mentioned in their list.

While the findings of Cheng et al. [25] are mainly focused on the broader impact of GPP implementation, another widely studied research topic is GPP and its interrelations. Specifying this aspect, Reference [26] showed the importance of external stakeholders on GPP. Environmental certification is another influencing factor for GPP and also for its relation to its stakeholders. In this context, Reference [27] found that GPP's influence on the market and its pressure in requiring certificates is positively associated with this certification practice.

Regarding CE aspects specifically, the Web of Knowledge database provided 16 hits for the search term 'circular procurement' in the area of management, business, economics, and law. Based on further analyses of titles and abstracts, eight articles appeared to be relevant in the context of this study [28-35]. Several CPP studies focus on a specific country case. In this context, four national studies were identified, including two from the EU member state The Netherlands (which include suggestions for public procurement in Sweden), as well as studies on Oman and Pakistan. German case studies were not identified in this review. Relevant product groups covered by the studies include building products, textiles, and ICT products. Specific analyses on circular public procurement in the automotive sector and the procurement of circular tyres are missing from the identified list. An additional analysis of grey literature showed several short examples for national procurement practices, in particular in EU documents such as [23]. There is also a German guide on environmental public procurement of tyres in general [36]. Key CE aspects such as recyclability and recycled content are, however, not addressed specifically. As this second example shows in particular, a gap regarding circular tyre procurement remains, also due to the poorly established practice of the topic. On this basis, two research questions were formulated:

(1) What is the current state of circular public tyre procurement in Germany?

(2) How could circular public procurement of these products be promoted?

After this introduction, Section 2 presents the materials and methods used to answer our research questions. Section 3 provides information on procurement patterns and barriers to procuring sustainable $\mathrm{CE}$ tyres, and solutions to address these barriers. The article finishes with a discussion in Section 4 and an outlook in Section 5.

\section{Materials and Methods}

The research work undertaken for this study took place in the EU member state of Germany. After providing an overview of current practices in Germany and the role of sustainability and circularity aspects in these processes from the literature, this section describes the research methods used in this study to investigate the specific public procurement situation of CE tyres in Germany.

\subsection{Status of Sustainable Public Procurement in Germany}

The content of this section is divided into the following three sections: first, an introduction to public procurement in Germany in general; second, information on the legal framework for sustainable, circular public procurement in particular; and third, information on appropriate measures to initiate sustainable public procurement for a certain product group. 


\subsubsection{Public Procurement in Germany}

Public Procurement Processes

Germany's public procurement has a volume of around $€ 500$ billion. Local authorities account for the largest share by far [37].

Public procurement processes are divided into different phases whose intensity varies according to each procurement transaction's content, extent, or customary nature. It begins with a needs assessment and analysis. Subsequently, the possibilities for addressing these needs are examined by market analyses. Concerning SPP, it must be checked whether sustainable variants exist for the product to be procured and whether a sufficiently large group of bidders exists for this. A bidder dialogue can also take place in this context. Then the tender documents are drawn up, in which sustainability aspects can be taken into account in various ways. After the subsequent publication of the award procedure, the bids received are examined, and the most economical bid is determined based on the predefined award criteria, cf. [38], p. 20.

Types of Public Procurement Procedure

The type of applicable procurement procedure is determined in particular by $\S 14$ of the Public Procurement Ordinance (Vergabeverordnung, VgV [39]). According to the VgV, the open procedure and the restricted procedure with a call for competition are always permissible as standard procedures. In addition, the negotiated procedure with a call for competition and the competitive dialogue, which also requires a call for competition, exists for special cases. This is particularly simple if the contract value is less than $€ 1000$, see Figure 1. In this case, § 14 of the Sub-Threshold Contract Regulations (Unterschwellenvergabeordnung, $\mathrm{UVgO}$ [40]) also facilitates the possibility of a direct contract, which is awarded without a formal procedure [38].

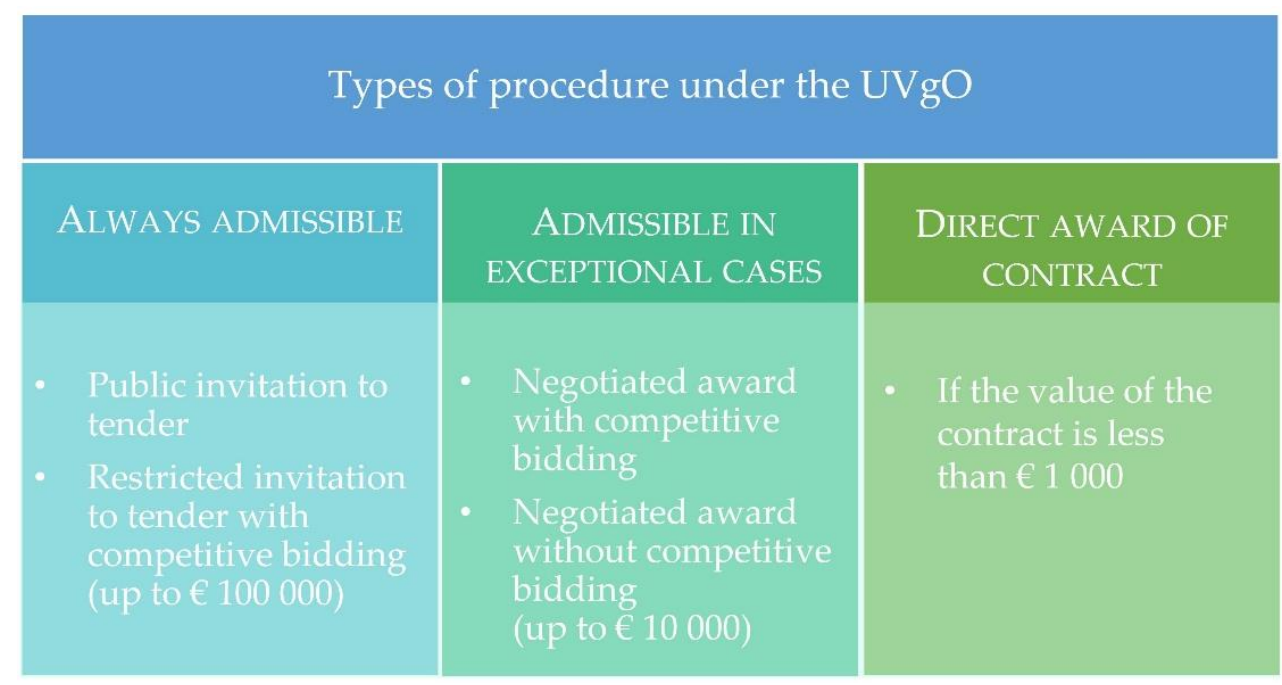

Figure 1. Procurement procedure according to the UVgO. Source: authors based on [41].

The $\mathrm{UVgO}$ is embedded in a regulatory framework, differentiating between two public procurement situations: buying nationally and European. EU-level procurement is required if an invitation to tender exceeds a threshold value. The value depends on the type of procurement organisation and the type of product or service in question and is adjusted regularly. Thresholds relevant in the case study are described in Sections 3 and 4 . When tendering, there is an obligation to tender in a product-neutral manner. In other words, contracting authorities may not specify a specific product to describe their needs [38], p. 21f. 


\section{Bid Evaluation Methods and Benchmarks}

Options for tender evaluation include the so-called interpolation formula or the socalled UfaB formula from the IT tendering and evaluation document (in German: Unterlage für Ausschreibung und Bewertung von IT-Leistungen, UfaB). With the more straightforward interpolation formula, the most favourable bid receives the maximum number of points. A bid that is (hypothetically) twice as expensive receives 0 points. Between these points, the points are interpolated linearly. A 50\% more expensive bid would thus only receive $50 \%$ of the maximum achievable points in the award criterion 'price'. In this way, the price is converted into a point value. The points achieved in this way in the criterion 'price' are then added to the points achieved in the other criteria (e.g., 'sustainability'). The bid that reaches the highest total in this way is awarded the contract [38]. For the criterion of 'price', this yardstick can be applied relatively simply with the purchase price. However, especially for environmentally sustainable procurement, it is also possible to take into account additional costs beyond the purchase price. This calculation of 'life cycle costs', which is permissible under Section 59 (1) $\mathrm{VgV}$, can be used to include ecological criteria such as electricity consumption or disposal costs in the calculation of costs, even in the case of a pure price assessment ([38], p. 30). The potential to consider life cycle costs is interesting in the case of tyres, because they impact fuel consumption levels depending on their rolling resistance.

\subsubsection{Legal Framework and Support for Sustainable, Circular Public Procurement European Law}

The Public Procurement Directive of 2014 (Directive 2014/24/EU of the European Parliament and of the Council of 26 February 2014 on public procurement) lays down the framework conditions for public procurement in the EU. It is decisive for procuring services in the public, and, especially, the municipal sector. Public procurement law's four general principles are the foundation of these regulations: transparency, equal treatment, nondiscrimination, and proportionality [38]. According to [38], the last principle, in particular, has a direct influence on (socially) sustainable procurement. Among other things, it sets limits on what the parties involved in a procurement procedure are expected to consider. This implies that sustainability aspects must not force bidders to demonstrate compliance with all social standards up to the last manufacturing stage if this can only be achieved with a disproportionate effort. The EU directives do not directly affect the member states, but require transposition into national law. For this purpose, the German directives were integrated into the already existing Act against Restraints of Competition (Gesetz gegen Wettbewerbsbeschränkungen, GWB) and supplemented by further regulations [38]. The national framework conditions of CPP are discussed in detail in the next section. Overall, the Supply Chain Act may lead to modified framework conditions.

\section{National Law}

The implementation of the EU's public procurement directives, mainly Directive 2014/24/EU, into German law took place in 2016. Public procurement regulations with environmental relevance in Germany include (see [37] and related sources):

- the Act against Restraints of Competition (GWB),

- the Regulation on the Award of Contracts for Subthreshold Contracts (UVgO),

- the Public Procurement Ordinance (VgV),

- the Recycling Management Act (Kreislaufwirtschaftsgesetz, KrWG),

- the Klimaschutzgesetz (Climate Protection Act, KSG), added by additional, federal Climate Protection Acts in several Federal States

- Regulations on the Award of Public Contracts for Construction Works, Parts A and B (VOB/A and VOB/B) (not relevant in the context of car tyres)

- Sector regulations (awarding of contracts in the fields of transport, drinking water supply, and energy supply by sector contracting authorities). 
These regulations give procuring entities extensive opportunities to procure sustainably and apply $\mathrm{CE}$ aspects consistently.

GWB (§97 para. 3) and UVgO (§ 2 para. 3) contain mandatory provisions according to which aspects of environmental protection must be taken into account when awarding contracts. For example, in the $\mathrm{VgV}, \S 31$ of the performance specification and $\S 34$ of the verification by means of quality marks are relevant. Based on $\S 34$, public contracting authorities can demand the submission of quality marks that prove the characteristics required in the performance specification. The conditions suggest that EU quality labels and also national quality labels fulfil these conditions. Details on the sustainability aspects in the regulations mentioned above are discussed in [42].

Section 13 of the Climate Protection Act explicitly contains a regulation on public procurement. In conformity with this document, the requirement to take climate protection into account and the goal of becoming climate neutral by 2045 apply to federal procurement agencies and to authorities of the German Federal States and municipalities that enforce federal law. Accordingly, the climate protection goals of the German government must be complied with in all phases of procurement, including the initial needs analysis. As defined in Section 13 (2) of the KSG, preference must be given to products that achieve the goal of reducing greenhouse gases over their entire useful life at the lowest cost. Therefore, life cycle costs and the economic costs for climate protection must be taken into account.

Paragraph $\S 45$ of the amended KrWG from 9 December 2020 also provides a new regulation for resource-conserving products and describes a preferential obligation for these products.

The new regulations support the environmental goals of the German government. Nevertheless, they do not force procuring entities to procure products that do not meet the intended use or give rise to unreasonable additional costs. Procurement law continues to apply, and Section 7 of the Federal Budget Code (Bundeshaushaltsordnung, BHO) on economy and thrift, cost, and performance accounting remains unaffected [37].

\section{Law of Germany's Federal States}

Germany's federal states have additional public procurement requirements. Climate Protection Acts, supplementing the KSG on several federal levels, were mentioned already. As an additional example, 12 of Germany's 16 federal states have procurement laws that anchor social sustainability in one form or another. Exceptions are Bavaria, Saxony, Hesse, and North Rhine-Westphalia. As a rule, the sustainability aspects are designed as special conditions of performance that must be complied with as part of the service provision [38].

Support for Sustainable Public Procurement: The Competence Centre for Sustainable Procurement and the Sustainability Compass

The Competence Centre for Sustainable Procurement (KNB) at the Procurement Office of the Federal Ministry of the Interior Building and Community supports public contracting authorities in taking sustainability criteria into account in procurement projects. The KNB is the central point of contact for all federal ministries, federal states, municipalities, and other public procurement agencies regarding sustainable public procurement. It is also a collaborator of Compass Sustainability, an important sustainability information tool in Germany.

\subsubsection{Initiation of Sustainable Public Procurement for a Product Group}

Due to the different framework conditions and characteristics of the various products and services requested by the municipalities, a step-by-step introduction of sustainability procurement aspects is often practiced. The products' and services' characteristics as well as their supply chains determine the availability of sustainable alternatives and, accordingly, the possibilities for successfully integrating sustainability criteria into tenders ([38], p. 12). 


\subsection{Research Method}

In order to answer the research questions on sustainable circular tyre procurement, the problem-centered interview, according to [43], was chosen. An interview guide was prepared to discuss procurement processes, barriers of circular tyre procurement, and the need for support to stimulate a more circular public procurement. Box 1 provides an overview of the interview topics. The research was conducted within the publicly funded German research project ConCirMy (Configurator for the Circular Economy), which aims to promote the tyre CE by the development of tyre configuration software and various activities in the fields of environmental engineering and socio-economic sciences by an interdisciplinary research team. More information can be found at the end of this article.

Based on the interview guide, 18 interviews with public procurement professionals directly entrusted with the purchase of tyres and 4 additional expert interviews were conducted between between 17 December 2020 and 27 April 2021. All persons were selected and contacted directly. Three times, six interviews were conducted, of which each discussed: (a) large scale procurement processes of at least 1000 tyres per year or contract; (b) procurement situations of at least 100 tyres within 12 months; and (c) the procurement of up to 100 tyres annually. An additional four interviews were conducted with a person of overarching expertise, two persons who either purchase tyres as part of vehicle procurement or vehicle leasing and a fourth expert particularly experienced in sustainable procurement strategies.

Box 1. Topics of the interviews conducted with the public procurement professionals.

- $\quad$ Procedures used for tyre procurement

- Software used for the procurement processes

- Decision criteria and indicators for the procurement of tyres

- Market analyses for the preparation of tenders

- $\quad$ Procurement of retreaded tyres

- United Nations Sustainable Development Goals and the Circular Economy Act in the procurement of car tyres

- Incentives that could stimulate the procurement of circular tyres

- Legal aspects

- Application scenarios for a tyre configuration software

- Priorities regarding a circular tyre value chain

- Information on the environmental and social performance of sustainable tyres

- Standards and labels/certification for sustainable tyres

- $\quad$ Request for further advice for the project

- Supplementary information on the organisations interviewed and their tyre pur-chasing volumes

Table 1 provides details. One person answered in great detail in written form. For privacy reasons, this contribution is not presented separately but counted as an interview of $\leq 30 \mathrm{~min}$.

The interview material was analysed by applying the qualitative social research method 'content analysis'. Content analysis is a method for surveying social reality, in which characteristics of a manifest text are inferred from characteristics of a non-manifest context (taken from [44], p. 57, translated). As [45] describes, qualitative content analysis is characterised by its systematic approach to the analysis of linguistic material. A central technique of qualitative content analysis is structuring. The goal here is to filter out a certain structure from the material. Mayring [45] describes the following variants (translated):

1. Formal structuring: wants to filter out the inner structure of the material according to certain formal structuring aspects.

2. Content structuring: wants to extract and summarise material on certain topics, on certain content areas. 
3. Typifying structuring wants to find individual distinctive characteristics in the material on a typifying dimension and describe them in more detail.

4. Scaling structuring: wants to define characteristics in the form of scale points for individual dimensions and assess the material on this basis.

Table 1. Interview overview.

\begin{tabular}{|c|c|c|}
\hline Type of Public Organisation * & $\begin{array}{c}\text { Tyre Demand Per Year or Contract Period } \\
\text { (Range) }\end{array}$ & Interview Length (Range) \\
\hline Organisation with overarching expertise & NA & $31-60 \mathrm{~min}$ \\
\hline Public procurement office & $>10,000$ & $\leq 30 \mathrm{~min}$ \\
\hline Central procurement office & $5001-10,000$ & $31-60 \mathrm{~min}$ \\
\hline Central procurement office & $5001-10,000$ & $31-60 \mathrm{~min}$ \\
\hline A municipal waste management company & Several thousand tyres in 3 years & $\leq 30 \mathrm{~min}$ \\
\hline Central procurement office & $1001-5000$ & $\leq 30 \mathrm{~min}$ \\
\hline The central fleet of a Federal State's police & $1001-5000$ & $31-60 \mathrm{~min}$ \\
\hline Central fleet management of a big city & $501-1000$ & $31-60 \mathrm{~min}$ \\
\hline Procurer for municipalities & $251-500$ & $\leq 30 \mathrm{~min}$ \\
\hline The waste management company of a district & $251-500$ & $\leq 30 \mathrm{~min}$ \\
\hline $\begin{array}{l}\text { A municipal company for street cleaning and } \\
\text { waste disposal }\end{array}$ & $251-500$ & $\leq 30 \mathrm{~min}$ \\
\hline The waste management company of a municipality & $101-250$ & $31-60 \mathrm{~min}$ \\
\hline $\begin{array}{c}\text { Office for waste disposal, street cleaning, and } \\
\text { vehicle fleet of a city }\end{array}$ & $101-250$ & $\leq 30 \min$ \\
\hline Public utility & $<100$ & $\leq 30 \mathrm{~min}$ \\
\hline Technical service of a city & $<100$ & $\leq 30 \mathrm{~min}$ \\
\hline Central garage of a district & $<100$ & $\leq 30 \mathrm{~min}$ \\
\hline A city's company for waste, streets, and greenery & $<100$ & $\leq 30 \mathrm{~min}$ \\
\hline A district office & $<100$ & $31-60 \mathrm{~min}$ \\
\hline A district office & $<100$ & $>60 \mathrm{~min}$ \\
\hline A district office & $\begin{array}{c}<100 \\
\text { (sustainable } \\
\text { procurement unit) }\end{array}$ & $\leq 30 \mathrm{~min}$ \\
\hline Major city & N.a. but approx. 700 vehicles & $31-60 \mathrm{~min}$ \\
\hline Procurement unit of a public institution & $-(\approx 100$ leased vehicles $)$ & $\leq 30 \mathrm{~min}$ \\
\hline
\end{tabular}

* For privacy reasons, the order is not linked with the case numbers in Section 3.

As an example for a qualitative content analysis, Mayring [45] analyses interviewbased material on 'stress in the professional field'. Two assessment dimensions with the following expressions are applied: 'stress assessment' (stressful-relieving-ambivalentirrelevant) and 'degree of stress' (no-weak-strong stress).

For the preparation of our research article, the methods of formal and typifying structuring were of particular importance. Originally, only formal and content structuring was planned for deriving recommendations for policymakers. Supplementary typifying structuring was undertaken after the material surprisingly revealed a pattern of types. The relevant dimensions of this typifying structuring were derived from the analysis of the material. The findings were analysed according to three topics: 1 . Procurement situations; 2. Barriers to CPP; and 3. input for recommendations to overcome them.

\section{Results}

\subsection{General Observations}

A first analysis of the interviews identified six patterns of public tyre procurement shown in Figure 2. The figure shows three basic types, which differ regarding the extent and complexity of the procurement processes and tyre procurement for specific applications. 


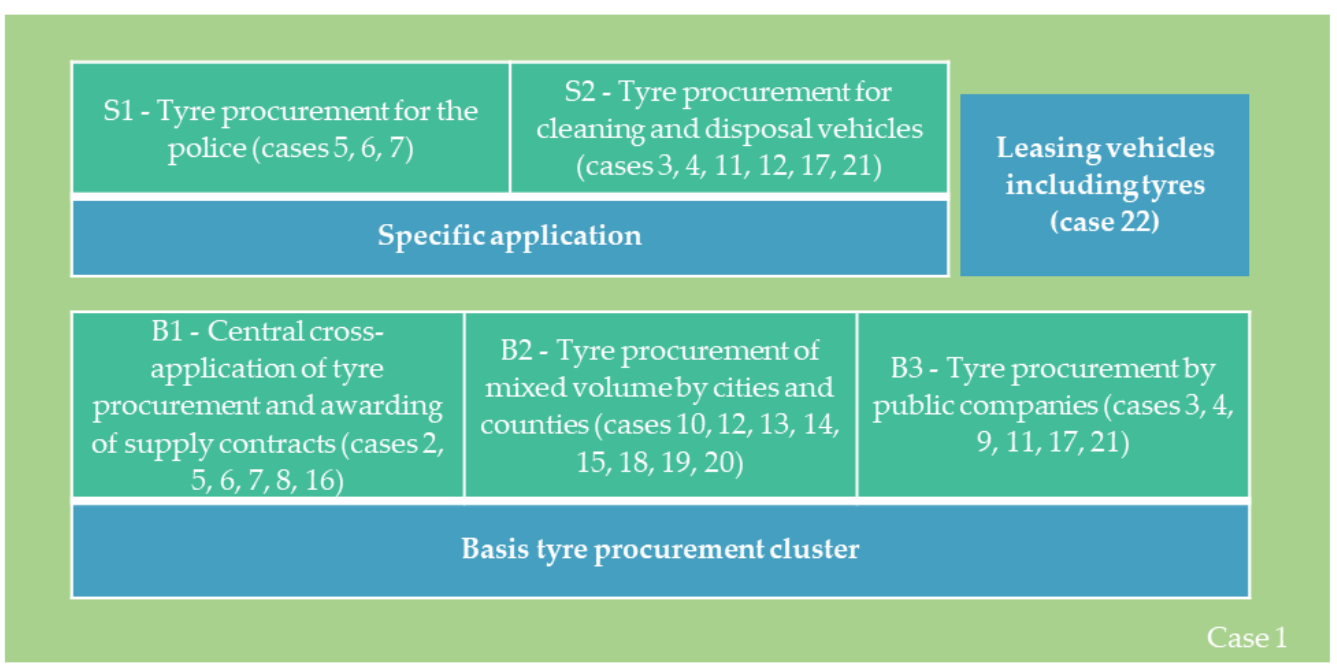

Figure 2. Summary of the procurement situations in the interviews.

The first basic type of tyre procurement takes place as central cross-application tyre procurement and awarding of supply contracts. It was observed in six cases of this study. The tyre procurement volume is often several thousand tyres per year, respectively, and EU-wide tenders are the dominant type of purchasing. Tyre procurement of mixed volume by (a) cities and counties and (b) public companies are the two other basic types: The interviewees referred to tyre procurement in high and low quantities, providing particular insight into volume-related differences in the CPP processes, also compared with big EU-level tenders.

Tyre procurement for specific applications refers to tyres for the police, street cleaning, and municipal waste disposal services. Vehicle leasing represents another specific framework in the tyre purchasing context.

The interview series included three interviews on the procurement of tyres for police cars. All three interviewees procured tyres in high quantity, particularly on the EU level. The sectors in which tyre procurement by cities and municipal companies for street cleaning and municipal waste disposal services takes place tend to use retreaded truck tyres more frequently than other sectors. Sometimes, they benefit specifically from particular functional characteristics of these tyres. Tyres are procured through national or European tenders.

Unique aspects became visible in the leasing context and laid the foundation for specifying the additional cluster 'leasing vehicles including tyres'. The vehicles' initial tyre sets are of particular importance there. Leased vehicles can usually be used with the initial sets of tyres over the entire contract period. The cluster includes one case, which represents all typical framework conditions of this type of tyre use. Other interviewees of this study were also familiar with this leasing situation and could give additional input to specify the characteristics of this cluster.

The interviewees provided a detailed description of the regulatory and market-related framework conditions of circular tyre procurement. They also unveiled very different procurement situations, not only depending on the procurement volume but also the specific framework conditions of the purchases, e.g., whether tyres for passenger cars or trucks were being purchased, the state of green public procurement in the interviewees' organisations in general, and the experiences of the procurement professionals. However, as mentioned in Section 2, the material showed the particular need for a more typifying structuring of the interviews' content. On this basis, four clusters of procurement situations with typical characteristics were distinguished. They are described in the next section. 


\subsection{Classification of Procurement Situations}

Based on further analyses of the interviews, four specific CPP profiles shown in Figure 3 were observed. They are differentiated by the current degree of $C E$ practice on a continuum between 'low' and 'high' and the current number of perceived CE opportunities on a continuum between 'few' and 'many'. One interviewee discussed sustainable tyre aspects on a higher level and was therefore not included in the classification. Another interviewee, whose organisation was also not classified, was not sure about the current use of retreaded tyres there because this procurement manager had just taken up employment.

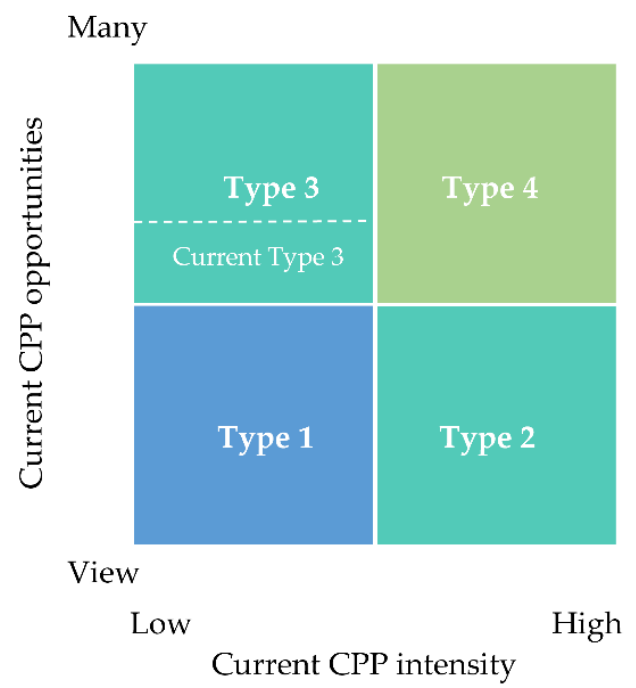

Figure 3. Classification of tyre procurement in terms of current CE level and CE implementation opportunities.

Since most of the remaining organisations procure tyres for different purposes and, therefore, with various functional requirements, belonging to several clusters is possible according to the relevant contexts. The current supply of sustainable tyres is mainly related to the offer of retreaded tyres. Therefore, the classification of procurement situations pays particular attention to the procurement of these tyres whenever possible. However, individual procurement situations sometimes require the consideration of other aspects, e.g., in the case of case no. 8 (see details below).

One group of the study's typical type 1 organisations with a low intensity of tyre CPP and few current tyre CPP opportunities consists of organisations entrusted with tyre procurement for the police. Tyres used for emergency vehicles require the best possible functional characteristics, which cannot be compromised in favour of common CE products. Public procurers hindered in procuring sustainable tyres due to gaps in procurement law are also part of this cluster. The third group of cluster 1 representatives includes organisations whose car fleets mainly consist of passenger cars, for which appropriate sustainable CE tyres are not available yet. Likewise, organisations that lease their vehicles face limited opportunities for circular tyre procurement.

Representatives of type 1 organisations are, e.g., two public procurement organisations involved in the procurement of tyres for the police in the interview series. However, one interviewee described that they also had cars not used for core police tasks, for which retreaded tyres were procured in the past. An additional interviewee entrusted with the procurement of tyres for the police also considered procuring retreaded tyres for trucks not used for core police tasks but stopped this due to market problems (see cluster 3 for more details).

Type 1 organisations also include no. 15 with a passenger car fleet and no. 22, which leases cars only. Another representative of this cluster, the interviewee of case no. 14, described the barrier of a limited supply of retreaded tyres with appropriate properties, e.g., no availability for electric vehicles. This person also spoke about a technical barrier. 
Using a mix of tyres is not possible in Germany. Therefore, replacing a tyre with a retreaded one would require replacing all the relevant car's current tyres with retreaded ones.

Although linked with few CPP opportunities, a higher CPP intensity is visible in the tyre procurement of type 2 organisations, represented by the organisations no. 2, no. 3 , no. 4 , no. 12 , and no. 21. The study's typical organisations of this type are municipal companies in street cleaning and waste disposal, which procure, in particular, truck tyres, represented by no. 3, no. 4 , no. 12 , and no. 21 . Due to specific properties-e.g., reinforced carcasses-retreaded tyres are increasingly used, and in some cases, tyres are regrooved. The use of these CE products is established in this group. Opportunities for procuring other sustainable $\mathrm{CE}$ tyres are, however, limited. This cluster may also include organisations (here, in particular, no. 2) that usually use large-scale tyre tenders, who are, besides their consideration of retreaded tyres, hindered in procuring sustainable tyres for additional applications by gaps in procurement regulation, in particular regarding clear CPP guidelines. Organisation no. 8 procures tyres for various purposes. It considers, e.g., fuel efficiency already but does not procure retreaded tyres. Currently, it explores opportunities for the procurement of more sustainable tyres as a strategic measure of its sustainability department. This indicates that the organisation regards the current intensity of its CPP as being medium, which we rank at the border between clusters 1 and 2 . The result of its strategic analysis will show to what extent it can become a type 2 or even a type 4 organisation.

The type 3 cluster with low current tyre CPP intensity, but a certain number of opportunities for tyre CPP include, in particular, municipal companies in the street cleaning and waste disposal sectors, which have used retreaded tyres only to a limited extent to date. In this context, many interviewees said they stopped using these tyres because the quality was not satisfying, e.g., for cases no. 9 , no. 11, no. 13, and no. 20. While options with better quality were unknown to these professionals, the use of retreaded tyres was considered quite possible by several interviewees. However, the interviewees of no. 15 and no. 7 stated that the current price level of retreaded tyres was not attractive to compensate for properties these tyres are missing compared with new ones. The interviewee of no. 10 described that they have a proven tradition of buying new tyres.

The interviewee of no. 16 described that tyre replacement is undertaken by the vendors of their trucks. According to this person, tyres are of minor importance in this context, and low attention is given to them. The interviewee of no. 19 first learned about retreaded tyres in the interview. However, this person suggested that the mileage of the tyres was an important factor in their tyre procurement decisions. In addition, no. 19's organisation as a whole is very active in implementing sustainable public procurement processes. Effects on tyre procurement processes are also expected in this context.

One reason why only a few organisations are classified as type 3 is related to limited offers of new tyres marketed as sustainable and or circular for broader use in the market. Since their availability is still limited, shown by the dotted line in Figure 3, opportunities of becoming a type 3 organisation or an organisation of the below presented type 4 are limited at the moment, except for the segment of retreaded truck tyres.

Type 4 organisations are those where tyre CPP plays an important role today-i.e., sufficient opportunities for CPP exist and are applied extensively. They share certain characteristics of both the type 2 and the type 3 cluster. Like the type 2 cluster, they use retreaded tyres in the truck sector already, for example. Like type 3 organisations, they also have a large fleet of passenger cars that could be equipped with $C E$ tyres. However, since the supply of CE-based passager car tyres is still limited, this type of organisation was not typical in the case study. When the tyre value chain becomes more circular, both current CPP intensity and CPP opportunities will rise for both truck tyres and passenger car tyres.

\subsection{Barriers to the Implementation of a Circular Economy}

As illustrated in Figure 4, the analysis of the interviews unveiled supply-side barriers regarding technical and market-related issues and demand-side barriers linked with regu- 
latory and social aspects. As a specific framework condition, several barriers are linked. A particular example is the limited supply of sustainable tyres, which is also influenced by a perception of little demand for them on the side of the tyre suppliers.

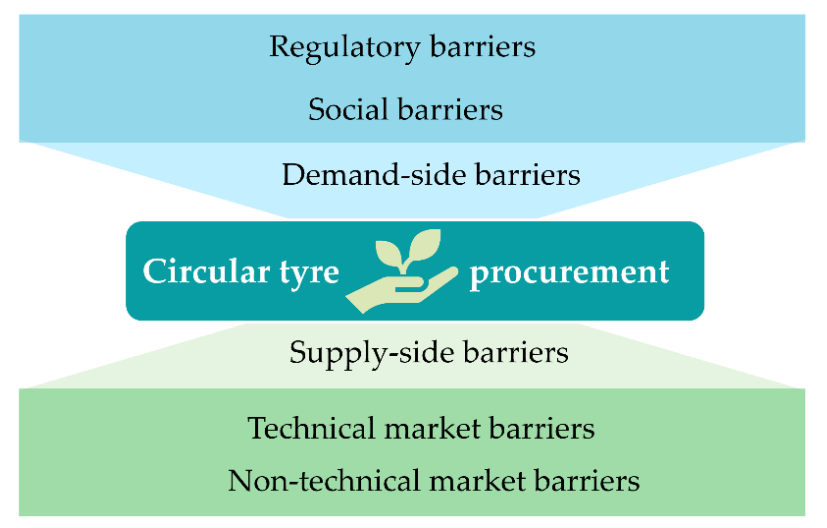

Figure 4. Barriers to sustainable circular tyre procurement. (C) authors.

\subsubsection{Supply-Side Barriers}

Supply-side barriers include technical and non-technical market barriers. Technical market barriers refer to situations in which the technical requirements for tyres are so specific that the market offers almost no opportunities to combine these properties with sustainability characteristics. This barrier relates in particular to the special safety requirements of the police, according to the interviewee of no. 6. As another technical barrier, this interviewee presented the difference of the carcasses as a hindrance to the use of retreaded tyres.

The inadequate offer of sustainable $\mathrm{CE}$ tyres is, however, the key non-technical market barrier for sustainable CE tyres. According to the interviewee of no. 7, uncountable tyres are on the market, and their life cycles are short. A tyre CE requires myriad varieties of sustainable CE tyres. However, due to the current demand, providing sustainable $\mathrm{CE}$ versions for all these tyres is not attractive for the producers, according to the interviewee of case no. 7. Interviewees also highlighted the problem of missing standards and certificates for sustainable CE tyres, e.g., regarding evaluation criteria. Concerns were also expressed concerning additional costs for proper disposal.

\subsubsection{Demand-Side Barriers}

Demand-side barriers consist of regulatory and social aspects. The dominant regulatory barrier is uncertainty regarding procurement law. It occurs in particular in the context of big-size tyre tenders. In particular, the interview of no. 2 highlighted this problem. A closely related issue is again the absence of specific standards and certificates. In this context, the interviewee of no. 6 mentioned, e.g., the exclusion of retreaded tyres from the scope of the EU tyre label. Interviewees also mentioned that the police of several federal states are only allowed to procure new tyres, also for cars and trucks not used for core policy duties.

The interview series also unveiled various social barriers. The first one, lack of awareness, frequently results in tyres not specified in vehicle tenders. Vehicle suppliers that win the eventual bid deliver the cars with a standard set of tyres. When vehicles are leased, leasees are often in the situation of never dealing with the procurement of tyres. The cars are usually returned after two years-i.e., before tyre replacement is required. Lack of trust is a problem as well. In this context, safety problems and perceived safety problems are often closely linked. As the third social barrier, the change to CPP is also related to additional efforts and the need for human resources. 
Another significant barrier consists of improper incentives to procure retreated tyres. The interviewee of no. 7 emphasised-e.g., that the typical prices of retraded tyres are almost as high as those of new ones of significantly better quality.

\subsubsection{Occurrence of the Barriers in the Clusters}

The occurrence of the specific barriers in the four procurement clusters differs. Type 1 organisations may face all kinds of barriers. In two other clusters, particular types of barriers are the most significant. Regarding public tenders of large volumes, for example, non-technical market barriers and regulatory ones may have specific importance. Type 2 organisations found niches to procure sustainable circular tyres. Their opportunities to use sustainable tyres are limited, mainly to retreaded tyres, but demand and supply are harmonised. Type 3 organisations face mainly non-technical market barriers, if retreaded tyres are not offered at reasonable prices. Likewise, they experience social barriers, e.g., as an absent willingness to try retreaded tyres because of bad experiences in the past. In contrast, type 4 organisations are located in an environment in which the intensity of barriers is low overall.

\subsection{Policy Recommendations to Promote Tyre CPP Derived from the Interviews}

Based on the interviews and the specific suggestions by the interviewees, nine recommendations for policymakers to support tyre CPP could be derived.

Recommendation 1-Update regulations to facilitate circular tyre procurement: The first recommendation addresses regulatory and non-technical market barriers in particular. The interview series showed a need for changes in legislation. In particular, the interviewees of no. 2 and no. 5 provided various suggestions. The interviewee of no. 2 required more clarity in procurement law to make sustainable circular tyre procurement possible. This includes clarity of what 'sustainable CE tyres' mean and how procurement professionals have to deal with them in their specific contexts. One option, suggested by an interviewee of no. 5 , is to make justification mandatory for non-sustainable publicly procured tyres. In several interviews, such as the interviewees of no. 14 and no. 17, reference was made to service directives or council resolutions. Recommendations 2 and 3 will deepen the considerations made here. As an additional measure, the interview of case no. 5 suggested financial support for sustainable tyre procurement.

Recommendation 2-Help the market in implementing CPP compliant procurement processes: This second recommendation addresses regulatory and market barriers again. The need for evaluation procedures that comply with procurement law was particularly mentioned in the interviews on no. 2 and no. 6. Promoting the development of evaluation processes can rely, e.g., on standardisation mandates and policies on labelling and certification. This was practised in the past, e.g., by the establishment of the EU tyre label, which is, however, mainly focussed on fuel efficiency, road safety, and rolling noise, not specifically on circular material aspects.

Recommendation 3-Classify tyres as a priority product for sustainable public procurement: Recommendation 3 addresses regulatory barriers in particular. According to [38], sustainable procurement requires documented prioritisation. Multiple 'priority products' of sustainable public procurement have already been defined in Germany. Sustainable CE tyres can only be suitably integrated into public procurement if they are also defined as a priority product, cf. interview on no. 20.

Recommendation 4-Facilitate the national procurement of retreaded tyres: The interviewee of no. 16 described that retreaded tyres are promoted by an increased threshold for EU tenders in favor of a national tender based on the declaration as a 'social service'.

An additional recommendation is to promote sustainable CPP also at the national level for retreaded tyres, but without creating a barrier for an extension to the European level. This could be done by promoting the establishment of an EU label for retreaded tyres. Another option is to check whether the procurers' reservations can be proven 
wrong, e.g., through information campaigns (Recommendation 5) or successful pilots (Recommendation 8).

Recommendation 5-Conduct information campaigns: Recommendations 5 and 6 address additional social barriers. The interview series clearly showed an information deficit regarding sustainable $\mathrm{CE}$ tyres. The importance of addressing different actors in the tyre procurement process and their various ways to influence tyre selection concerning sustainable $\mathrm{CE}$ aspects by targeted information measures became clear. Information campaigns could also help remove reservations regarding retreaded tyres, for example.

Recommendation 6-Provide appropriate information tools: The interviewee of no. 18 described the need for appropriate IT tools illustratively. A survey conducted in the interviewee's organisation demonstrated the demand for suitable software tools. The ConCirMy project addresses this need specifically. However, ensuring the long-term use of up-to-date information by procurement professionals will require additional measures.

Recommendation 7-Engage key stakeholders: Recommendation 7 addresses technical, market, and social barriers as well. The interview series led to specific individual recommendations to engage four particular stakeholders: opinion leaders as well as providers of vehicles, tyres, and leasing services. Concerning the involvement of opinion leaders, the automobile club ADAC was specifically considered. In addition, it is crucial to raise the interest of car dealers and leasing companies in tyre-related sustainability topics. A specific barrier to the spread of sustainable CE tyres mentioned by interviewees is leasing practices, because many sustainability aspects of tyres are ignored in this context. Therefore, engaging this target group is very important. ConCirMy plans to implement targeted measures to work with these stakeholders. However, more efforts as part of a national campaign will be necessary to reach an optimal level of engagement by these target groups (see also Section 4.2, including also a signalling of the demand side's interest in sustainable CE tyres).

Recommendation 8-Conduct pilot projects: The interviewee of no. 1 suggested pilot projects to implement tyre CPP explicitly. The interviewee of case no. 18 provided an illustrative example of such a project on a municipality level, although without a nationwide reach or a specific tyre focus. Section 4 will provide detailed suggestions for conducting a national pilot project on tyre CPP. Model regions and similar experimental approaches are popular in Germany. This may provide attractive framework conditions for the realisation of such a pilot project.

Recommendation 9-Check the feasibility to increase the threshold for European tenders for sustainable tyres: The last recommendation addresses the social barriers of limited procurement resources. It suggests linking CPP with certain simplifications and thereby provides a specific stimulus for circular public procurement. Specifically, it suggests increasing the threshold value for sustainably procured tyres, in line with the modification of the threshold for procuring social services, which-according to the EU definition-also covers retreading tyres. This recommendation was described in detail by the interviewee of no. 16. By referring to [46,47], the interviewee explained that EU law attractively considers retreads as social services. In this context, Article 4 of EU directive 2014/24 specifies threshold amounts for EU tendering. While the threshold for public supply and service contracts is sightly above $€ 200 \mathrm{k}$, directive 20214/24 specifies a threshold of $€ 750 \mathrm{k}$ for public service contracts for social and other specific services listed in its Annex XIV. The interviewee recommended more simplifications by modifying tendering thresholds for all sustainable tyres and even sustainable products in general.

The topic of tendering thresholds and attractive exemptions was a unique element of one interview in our series and not repeated afterwards. For this reason, the recommendation was further analysed, and reasons for this uniqueness were identified. Formulating such a suggestion requires (a) specific insight into EU tenders, (b) particular insight into EU tendering of retreaded tyres, and (c) a specific sustainability orientation. Tendering retreaded tyres on high quantities that require EU tendering is currently rare, and searching for additional interviewees that might have come to the same recommendation did not 
appear promising. Instead, the suggestion was considered an innovative contribution to be directly included in this recommendation list.

One aspect which requires attention is, however, economic sustainability. In the public sector-in which taxpayers' money is spent-efficiency is of particular importance. EU tendering may facilitate the receipt of more offers and therefore raise the likelihood of receiving more attractive bids. Thus, the modified tendering thresholds should only be offered for a short period. Another reason for this remark is that many initiatives exist to make sustainable public procurement the standard one day. If this is realised, incentivising sustainable practices will not be necessary anymore.

\section{Discussion}

\subsection{Summary of Findings}

As shown in Section 2, state-of-the-art research on circular procurement regarding countries and specific products or product groups is limited. Furthermore, the automotive sector is not considered in depth. This article provides an analysis of the state of circular tyre procurement in Germany. Section 1 presents two research questions regarding the current state of circular public tyre procurement in Germany and options to promote this type of procurement. Based on state of the art in GPP research, [25] mentions barriers and supports but provides only a few examples of the latter. Product-specific barriers and supports are not considered by [25]. Our research contributed to a reduction of this gap based on two initial questions.

As a structured answer to question 1, a classification was developed. Based on the two dimensions of current tyre CPP intensity and current tyre CPP opportunities, four types of current tyre procurement situations were identified.

The clusters' organisations face supply-side and demand-side barriers, which hinder the successful implementation of circular tyre procurement. Regarding successful GPP, Liu et al., 2021 [26] emphasised the importance of external stakeholders. In the given context, their importance was also visible: the actions of tyre suppliers and an appropriate supply of suitable tyres is critical for successful CPP.

The circular procurement of tyres is currently linked with various demand-side and supply-side barriers. Addressing these barriers and responding to question 2, nine recommendations for policymakers to support tyre CPP are provided. Figure 5 shows our findings in the context of the state-of-the-art research presented by [25].

The suggestion on the pilot projects addresses most of the other recommendations from this article. This includes, in particular: the facilitation of sustainable retreaded tyres' procurement, regulatory support, information campaigns, appropriate information tools, and stakeholder engagement. However, the implementation of this recommendation requires more specific guidance. Section 4.2 specifies this recommendation in detail as a way forward.

The procurement classification for the market of sustainable CE tyres shows a specific example for the procurement situations of markets in transition to a sustainable and circular economy and can be further applied in this context. It can be used as a strategic instrument to specify future-oriented procurement strategies: not only product-specific but also organisation-wide, in the public sector and beyond. Type 3 situations with low current CPP intensity and many CPP opportunities provide appropriate framework conditions to become more circular. In type 1 and type 2 contexts, the number of CPP opportunities is limited, while type 4 procurement does not face a current need for action. Nevertheless, it is important to monitor new opportunities for improved CPP and to adjust purchasing strategies accordingly. In this context, the classification can also be used to show internal goals and internal progress. Figure 6 shows an example. 


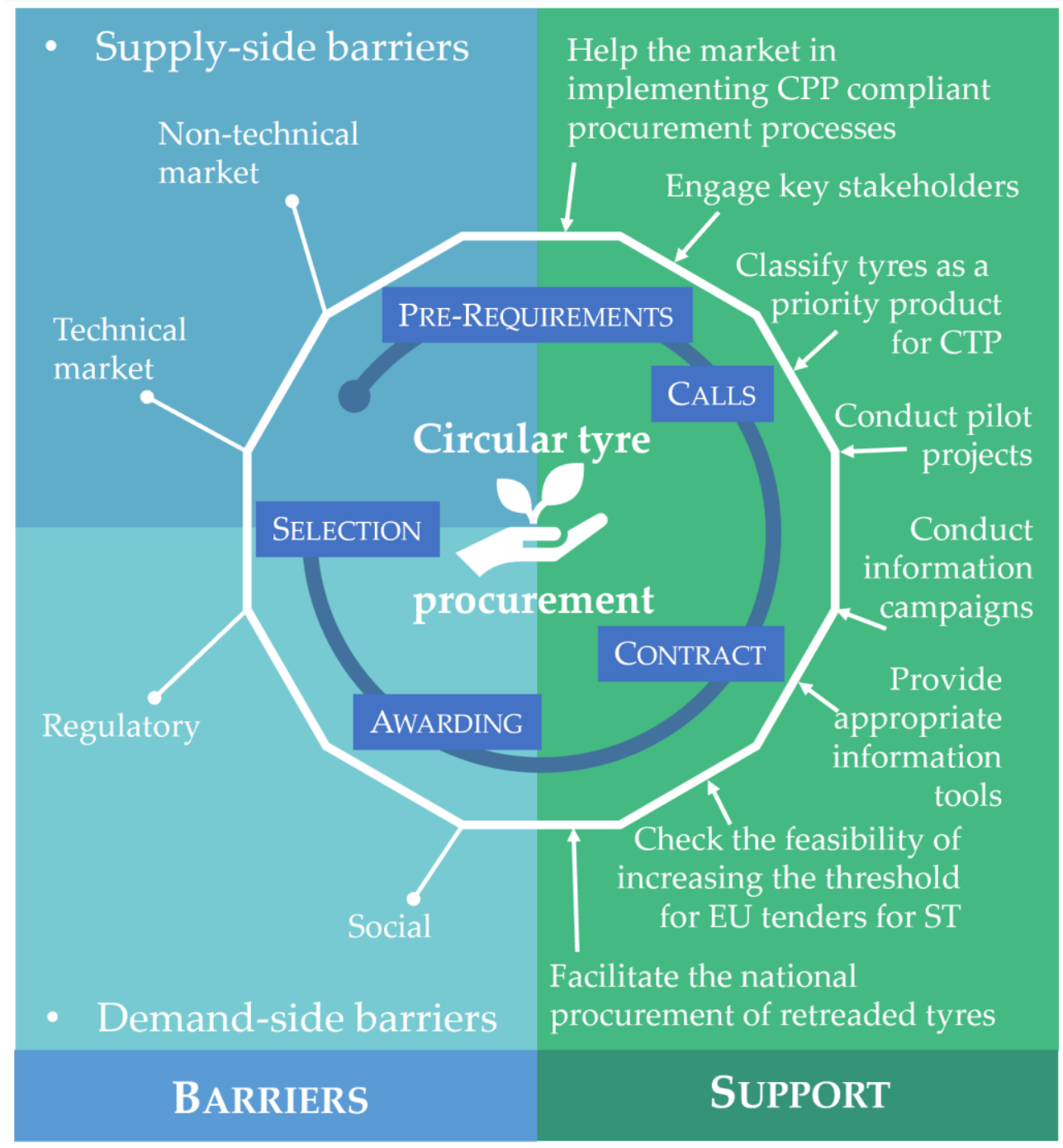

Figure 5. Contribution to research: circular public tyre procurement, barriers and reaction strategies. Source: authors, combining the state the art in [25] with own results.

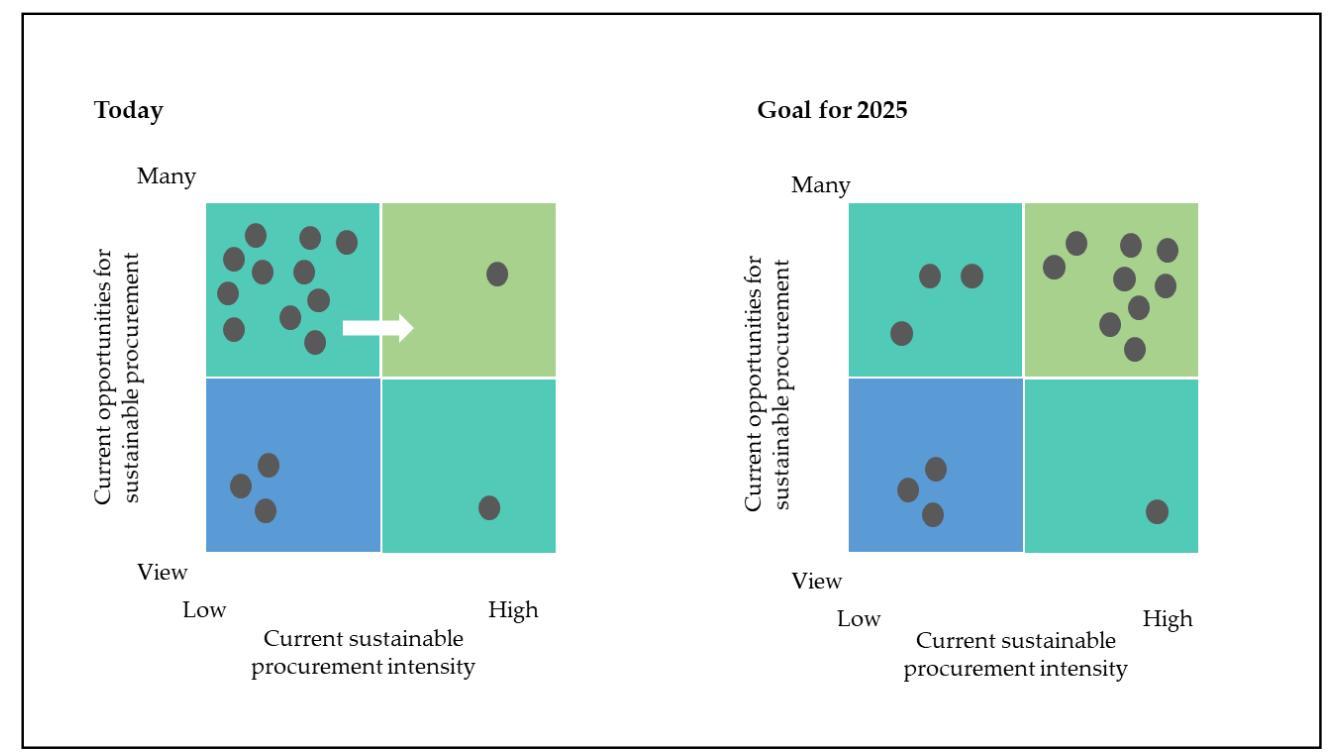

Figure 6. Example for the application of the sustainability-oriented public procurement classification in new contexts. (C) authors. 
Specifically, the classification could also be used as a benchmark instrument for extended sustainability-oriented analyses. These analyses could include, e.g., inventories of a single organisation's whole procurement range and comparisons of cities, regions, and even nations. The procurement of circular and bio-based products could be considered explicitly under this umbrella of sustainable procurement analyses. Regarding potential application fields, CE solutions for electric vehicles, for example, are a topic of growing importance $[48,49]$. Likewise, the markets for bio-based automotive and electronic products are rising [50] and provide appropriate application fields for this reason.

\subsection{Way Forward: Draft of a National Tyre CE Pilot Project}

A specific recommendation in Section 3 was given to set up a pilot project. Pilot projects are 'policy instruments mainly applied to introduce or test new practices, concepts or technologies' [51], p. 1. 'Often used in policy and management contexts to apply and adapt an innovation to a real-world situation', they are conducted 'to test innovations and to develop knowledge about the interactions of the innovation and the context' [37]. Pilot projects are particularly considered a means to deal with the complexity of socio-ecological systems, enhance communication across actors and domains, set the agenda and streamline resources (see [51], p. 1, and the sources mentioned there).

For the implementation of a pilot project according to recommendation 8, [28] offers helpful insights and experiences based on a Dutch CPP project for textiles. The pilot was part of several research projects, including a demonstration project carried out between 2013 and 2016. Based on the findings of [28], the structure of a possible tyre CPP pilot project is outlined below. The Dutch CPP project consisted of five stages, which the present research extends by an additional evaluation stage. The proposed project addresses not only recommendation 8, but also the previous recommendations in Section 3.4-e.g., recommendations 5-7. In line with the interviewees' suggestions, specific emphasis is also put on standardisation and the need for regulatory adjustments (recommendations 1-4).

\subsubsection{Ensuring Alignment and Commitment}

Year 0: Policymakers declare interest in tyre $\mathrm{CPP}$ and entrust an organisation such as the KNB with the coordination of the pilot project.

Year 1: From the beginning, the industry, particularly providers of vehicles and tyres, is significantly involved in the formation of the project. The plans of different tyre vendors for the years from 2022 onwards (see, e.g., [52]) seem to fit well into this framework. Tyre companies are given formal assurance that price is not the decisive selection criterion when awarding contracts in the context of the project but that environmental and social criteria will also be taken into account. A tyre association, ideally joined by a vehicle association, acts as a central participant. In addition, representatives of the public sector, potential funding bodies and independent research institutes should be present during the development of the pilot. Since this proposed project aims at achieving greater sustainability and a more circular value chain, representatives of environmental associations should also be involved.

The parties design the project and create an initial action plan. A particular element of this plan is the specification of the organisation that will act as the project's pilot procurer and carry out the procurement.

At the beginning of the implementation phase, an intermediary takes over preliminary category management for the product group 'tyres' on behalf of the Ministry of the Interior and is responsible for details regarding category management, contract management, and the material system regarding the product group. Intensive information exchange with procurement bodies takes place regarding future needs on the one hand and implementation options on the other hand. Targeted work aims to link the various requirements.

The following work is dedicated to formalising the pilot procurement's objectives to support operational planning and logistics for the procurer and communicate the procurement plans to the market. This communication is scheduled two years before the tender. This measure is intended to help tyre companies to respond appropriately based on realistic 
preparation schedules. As a final step of the first stage, the category manager publishes common objectives between the procurer and the potential suppliers of the pilot project.

\subsubsection{Market Signalling}

Year 2: Stage 2 begins with market signalling with a key objective of giving potential suppliers sufficient time to prepare their bids. Promoted by targeted invitations by the industry association, supplier workshops are held to gather input, explore alternatives, and strengthen the project's feasibility. An electronic request for information may be published on an electronic procurement platform.

The category manager actively cultivates relationships with the suppliers. In doing so, emphasis is put on taking into account the different situations and attitudes of these stakeholders. Another activity is dedicated to the stimulation of new CE-related company partnerships, also involving other stakeholder groups. Not only in the tyre context, but regarding CPP in general, platforms with information on stakeholders such as the one developed in the ConCirMy project can facilitate these collaborations and reduce search efforts and costs.

\subsubsection{Strategic Partnerships with the Business Community}

Year 3: Phase 3 lays specific foundations for persistent project results. The industry association establishes a circularity working group with the category management's involvement. In parallel with the creation of this paper, the Bundesverband Sekundärrohstoffe und Entsorgung (BVSE) created a working group on tyres in the recycling industry. Options to extend this working group for the purpose of the pilot project could be checked.

\subsubsection{Implementation of Aspirations and Capabilities}

In phase 4 , the information previously gathered in the pilot project is transferred into a draft tender. Based on the experience of [28], particular attention will be paid to clear role definitions and readiness to redefine priorities in terms of environmental and economic aspects.

\subsubsection{Finalisation of Specifications and Criteria}

End of year 3: Optimised procurement processes shape the final phase of the pilot tender. Based on the tender, bids are selected. The role of intermediaries is minimal in this phase.

\subsubsection{Evaluation}

Six months after the award of the contract, the lessons learned from the pilot are jointly formulated. Special attention is paid to regulatory implications, implications for standardisation pursued with the particular involvement of the stakeholders of the strategic partnership, and organisational process design on the side of the procurement organisations.

\section{Discussion and Conclusions}

\subsection{Contribution to Research and Practice}

This article analysed suitable strategies to implement CPP in the specific product area of tyres and aimed to enrich CPP research by in-depth product-specific analyses. As a starting point, it investigated the current state of circular tyre procurement in Germany. Based on the dimensions 'current circular public procurement (CPP) intensity' and 'current CPP opportunities', four types of tyre procurement situations were identified.

Strategies to overcome the various barriers were specified, resulting in nine recommendations for German policymakers. One recommendation referred to certification. In this context, Ma et al. (2021) [27] found that GPP market pressure is positively associated with environmental certification practice. In the tyre context, even policymakers specified certification in the past, although not regarding CPP aspects. In any case, tyre certification 
modified to consider circularity aspects could not only support procurement processes but also stimulate pro-environmental behaviour on the suppliers' side.

As a way forward, a detailed concept for a circular public tyre procurement pilot project is provided. Sönnichsen and Clement [53] described the potential support for a CE by the dissemination of best practices. Specifically, they list three sources showing that the "(d)issemination of best practices ( ... ) enable(s) effective support for developing implementation of circular principles". For this reason, not only the pilot project will be important, but also an appropriate analysis of its outcome. Lessons learned and resulting guidance will be essential to facilitate circular public tyre procurement in the future. Support for this recommendation also comes from abroad. In this context, [23] described how the Dutch Government established a program to accelerate the transition to a CE. This programme brought together 45 public and private parties. Eighty circular procurement pilots were conducted, and their lessons shared.

Regarding CPP in a broader context, this article identified four procurement clusters in terms of current CE level and CE implementation opportunities. The study's type 1 cluster is characterised by a low intensity of tyre CPP and few current tyre CPP opportunities consists of police organisations. Although linked with few CPP opportunities, a higher CPP intensity is visible in the tyre procurement of type 2 organisations, represented by the organisations. Type 3 organisations have a low current tyre CPP intensity but a certain number of opportunities for tyre CPP. Type 4 organisations are organisations where tyre CPP plays an important role today-i.e., sufficient opportunities for CPP exist, and are applied extensively. The categorisation is particularly relevant for product markets in transition to a sustainable, circular economy, in which the opportunities to procure sustainable are subject to change.

\subsection{Limitations and Further Research Directions}

Content-wise, this article referred to Germany and its legal and market-specific framework conditions. On this basis, the first limitation refers to the future effect of the instruments it suggested. An analysis of Germany's future tyre procurement options, the implementation of this article's recommendations, and the suggested pilot project may help close this gap.

Measures for sustainable tyre CPP in other countries will require further research. As [53] highlights, the procurement rules and regulations, at least in Europe, are based on the same legal framework. Therefore, certain alignment can be assumed, and possible contextual differences will be mitigated in the future. As [53] further suggests regarding regional CE aspects, two questions require further research: (1) How do American and European countries within the OECD differ regarding their (sustainable and circular) procurement practices? and (2) To what extent could public procurement based on circular principles benefit emerging economies?

The suggested concept for the pilot project includes the KNB, a German intermediary which does not necessarily have a similar (partner) institution abroad. For this reason, pilot projects in other countries have to be designed in line with the national organisational structures.

As mentioned, [26] highlighted the importance of external stakeholders for successful GPP. In this context, it is also possible that the industry drives the market towards sustainability and circularity, making such tyres the standard. This would create totally new framework conditions for circular tyre procurement. In this case, the industry's way toward more sustainability would be the most important research aspect.

Author Contributions: Conceptualization: S.W., Investigation: S.W., Methodology: S.W., Writingoriginal draft: S.W., Writing-review and editing: S.W., R.S. and R.G.S., visualization: S.W. and R.G.S. All authors have read and agreed to the published version of the manuscript. 
Funding: The authors acknowledge the support by the German Federal Ministry of Education and Research (BMBF) (ConCirMy project, measure ReziProK, funding no. 033R236E), the German Research Foundation and the Open Access Publication Fund of TU Berlin.

Institutional Review Board Statement: This study relied on proven data management techniques of our institute. The article presented experts opinions and does not contain ethical critical data. A cross-check by the team confirmed that the article does not contain information which would make the interviewees identifiable. Ethical review and approval were waived.

Informed Consent Statement: Patient consent is not applicable to / required for this study since no patients were interviewed.

Data Availability Statement: Raw data is stored at TU Berlin according to our privacy declaration, according to which we treat personal data confidentially.

Conflicts of Interest: The authors declare no conflict of interest.

\section{References}

1. European Commission; Communication from the Commission to the European Parliament, the Council, the European Economic and Social Committee and the Committee of the Regions. A New Circular Economy Action Plan: For a Cleaner and More Competitive Europe. 2020. Available online: https:/ / eur-lex.europa.eu/legal-content/EN/TXT/HTML/?uri=CELEX:52020DC0 098\&from=EN (accessed on 27 September 2021).

2. United Nations Sustainable Development Goals. Goal 12: Ensure Sustainable Consumption and Production Patterns. Available online: https:/ / www.un.org/sustainabledevelopment/sustainable-consumption-production/ (accessed on 30 September 2021).

3. Kirchherr, J.; Reike, D.; Hekkert, M. Conceptualizing the circular economy: An analysis of 114 definitions. Resour. Conserv. Recycl. 2017, 127, 221-232. [CrossRef]

4. Acatech/Circular Economy Initiative Deutschland/SYSTEMIQ. Circular Economy Roadmap für Deutschland. 2021. Available online: https:/ / www.acatech.de/publikation/circular-economy-roadmap-fuer-deutschland/ (accessed on 27 September 2021).

5. Karagoz, S.; Aydin, N.; Simic, V. End-of-life vehicle management: A comprehensive review. J. Mater. Cycles Waste Manag. 2020, 22, 416-442. [CrossRef]

6. Campbell-Johnston, K.; Calisto Friant, M.; Thapa, K.; Lakerveld, D.; Vermeulen, W.J. How circular is your tyre: Experiences with extended producer responsibility from a circular economy perspective. J. Clean. Prod. 2020, 270, 122042. [CrossRef]

7. Lapkovskis, V.; Mironovs, V.; Kasperovich, A.; Myadelets, V.; Goljandin, D. Crumb Rubber as a Secondary Raw Material from Waste Rubber: A Short Review of End-Of-Life Mechanical Processing Methods. Recycling 2020, 5, 32. [CrossRef]

8. European Commission. Communication from the Commission to the European Parliament, the Council, the European Economic and Social Committee and the Committee of the Regions. Critical Raw Materials Resilience: Charting a Path towards Greater Security and Sustainability. COM 474 Final. 2020. Available online: https:/ / eur-lex.europa.eu/legal-content/EN/TXT/HTML/ ?uri=CELEX:52020DC0474\&from=EN (accessed on 27 September 2021).

9. Van Beilen, J.B.; Poirier, Y. Guayule and Russian Dandelion as Alternative Sources of Natural Rubber. Crit. Rev. Biotechnol. 2007, 27, 217-231. [CrossRef]

10. Fraunhofer. Better than Natural Rubber BISYKA Biomimetic Synthetic Rubber. 2019. Available online: https:/ /www.polymerpilotanlagen.de/content/dam/polymer-pilotanlagen/en/documents/Fraunh-fer_Brosch\%C3\%BCre\%20BISYKA_Englisch_ WEB.pdf (accessed on 27 September 2021).

11. Fraunhofer-Gesellschaft Kreislaufwirtschaft. Carbon Black aus Autoreifen Recyceln. Forschung Kompakt. 2021. Available online: https:/ /www.fraunhofer.de/de/presse/presseinformationen/2021/juli-2021/carbon-black-aus-autoreifen-recyceln.html (accessed on 27 September 2021).

12. Recovered Carbon Black. Hightech-Rohstoff Carbon Black. Available online: https://recovered-carbon-black.com/ (accessed on 27 September 2021).

13. BVSE. bvse-Ausschuss Recycling von Reifen und Gummi Gegründet. 2020. Available online: https://www.bvse.de/reifen-undgummi/themen-meldungen-ausschuss-reifen/6593-bvse-ausschuss-recycling-von-reifen-und-gummi-gegruendet.html (accessed on 27 September 2021).

14. Michelin. 100\% Sustainable: Disruptive Innovation in Biosourced and Recycled Materials. 2021. Available online: https: //www.michelin.com/en/innovation/vision-concept/sustainable/ (accessed on 27 September 2021).

15. ETRMA. Management Systems of End-of-Life Tyres. 2019. Available online: https://www.etrma.org/key-topics/circulareconomy / (accessed on 27 September 2021).

16. Reifen. Optimiert. 2012. Available online: https://azur-netzwerk.de/wp-content/uploads/Spritsparreifen.pdf (accessed on 27 September 2021).

17. Araujo-Morera, J.; Verdejo, R.; López-Manchado, M.A.; Santana, M.H. Sustainable mobility: The route of tires through the circular economy model. Waste Manag. 2021, 126, 309-322. [CrossRef] 
18. ZARE. Used Tire Recovery \& Recycling in Germany. Used Tire Recovery and Recycling in Germany 2019 (Tonnage) as of August 2020. Available online: https:/ / zertifizierte-altreifenentsorger.de/nachhaltige-altreifenentsorgung/altreifenverwertungin-deutschland/ (accessed on 27 September 2021).

19. Sienkiewicz, M.; Kucinska-Lipka, J.; Janik, H.; Balas, A. Progress in used tyres management in the European Union: A review. Waste Manag. 2012, 32, 1742-1751. [CrossRef]

20. Walter, C. PS WELT Materialcheck. Was Taugen Runderneuerte Reifen Wirklich? 2015. Available online: https:/ /www.welt.de/ motor/article138565689/Was-taugen-runderneuerte-Reifen-wirklich.html (accessed on 27 September 2021).

21. Wurster, S.; Schulze, R.; Simon, R.G.; Hoyer, S. A Grounded Theory on Sustainable Circular Public Procurement in Germany: Specific Product Case and Strategies. Sustainability. 2021, 13, 13525. [CrossRef]

22. European Commission. Policy: Public Procurement. 2021. Available online: https://ec.europa.eu/info/policies/publicprocurement (accessed on 27 September 2021).

23. European Union. Public Procurement for a Circular Economy: Good Practice and Guidance. 2021. Available online: https://ec. europa.eu/environment/gpp/pdf/CP_European_Commission_Brochure_webversion_small.pdf (accessed on 4 November 2021).

24. Commission of the European Communities. Communication from the Commission to the European Parliament, the Council, the European Economic and Social Committee and the Committee of the Regions. Public Procurement for a Better Environment. COM 2008. Available online: https:/ / eur-lex.europa.eu/LexUriServ/LexUriServ.do? uri=COM:2008:0400:FIN:EN:PDF (accessed on 4 November 2021).

25. Cheng, W.; Appolloni, A.; D’Amato, A.; Zhu, Q. Green Public Procurement, missing concepts and future trends-A critical review. J. Clean. Prod. 2018, 176, 770-784. [CrossRef]

26. Liu, J.; Ma, Y.; Appolloni, A.; Cheng, W. How external stakeholders drive the green public procurement practice? An organizational learning perspective. J. Oncol. Pharm. Pract. 2021, 21, 138-166. [CrossRef]

27. Ma, Y.; Liu, Y.; Appolloni, A.; Liu, J. Does green public procurement encourage firm's environmental certification practice? The mediation role of top management support. Corp Soc. Responsib. Environ. Manag. 2021, 28, 1002-1017. [CrossRef]

28. Rainville, A. Stimulating a more Circular Economy through Public Procurement: Roles and dynamics of intermediation. Res. Policy 2021, 50, 104193. [CrossRef]

29. Neessen, P.C.M.; Caniëls, M.C.J.; Vos, B.; de Jong, J.P. How and when do purchasers successfully contribute to the implementation of circular purchasing: A comparative case-study. J. Purch. Supply Manag. 2021, 27, 100669. [CrossRef]

30. Hald, K.S.; Wiik, S.; Larssen, A. Sustainable procurement initiatives and their risk-related costs: A framework and a case study application. Mol. Biol. Evol. 2021, 25, 230-243. [CrossRef]

31. Siminica, M.; Avram, M.; Roxana, L.P.; Avram, L. The Adoption of the National Green Procurement Plans from the Perspective of Circular Economy. Amfiteatru Econ. 2020, 22, 15-27. [CrossRef]

32. Gåvertsson, I.; Milios, L.; Dalhammar, C. Quality Labelling for Re-used ICT Equipment to Support Consumer Choice in the Circular Economy. J. Consum. Policy 2020, 43, 353-377. [CrossRef]

33. Al Hosni, I.S.; Amoudi, O.; Callaghan, N. An Exploratory Study on Challenges of Circular Economy in the Built Environment in Oman. In Proceedings of the Institution of Civil Engineers Management, Procurement and Law; ICE Virtual Library: London, UK, 2020; Volume 173, pp. 104-113. [CrossRef]

34. Zaidi, S.A.H.; Mirza, F.M.; Hou, F.; Ashraf, R.U. Addressing the sustainable development through sustainable procurement: What factors resist the implementation of sustainable procurement in Pakistan? Socio-Econ. Plan. Sci. 2019, 68, 100671. [CrossRef]

35. Dalhammar, C. The Application of 'life cycle thinking' in European environmental law: Theory and practice. J. Eur. Environ. Plan. Law 2015, 12, 97-127. [CrossRef]

36. Umweltbundesamt. Leitfaden zur Umweltfreundlichen Öffentlichen Beschaffung von Fahrzeugreifen. 2012. Available online: https:/ / www.nachhaltige-beschaffung.info/DE/DokumentAnzeigen/dokument-anzeigen.html?idDocument=45\&view= knbdownload (accessed on 26 November 2021).

37. BMU. Umweltfreundliche Öffentliche Beschaffung. 2020. Available online: https://www.bmu.de/themen/wirtschaft-produkteressourcen-tourismus/produkte-und-konsum/umweltfreundliche-beschaffung/ (accessed on 27 September 2021).

38. FEMNET. Möglichkeiten einer Ökologisch und Sozial Nachhaltigen Öffentlichen Beschaffung. Leitfaden Erstellt im Auftrag von FEMNET e.V. 2019. Available online: https: / / femnet.de/download/send/22-beschaffung/98-moeglichkeiten-eineroekologischen-sozial-nachhaltigen-beschaffung-femnet-leitfaden.html (accessed on 27 September 2021).

39. BMJV/BfJ. Verordnung über die Vergabe Öffentlicher Aufträge (Vergabeverordnung-VgV). 2016. Available online: https: //www.gesetze-im-internet.de/vgv_2016/ (accessed on 27 September 2021).

40. BMWI. Bundesministerium für Wirtschaft und Energie Bekanntmachung der Verfahrensordnung für die Vergabe Öffentlicher Liefer und Dienstleistungsaufträge Unterhalb der EU-Schwellenwerte (Unterschwellenvergabeordnung-UVgO)—Ausgabe. 2017. Available online: https://www.bmwi.de/Redaktion/DE/Downloads/U/unterschwellenvergabeordnung-uvgo.pdf?_ blob=publicationFile\&v=6 (accessed on 27 September 2021).

41. Siedenberg, A. Erfahrungen aus der Praxis Nachhaltiger Beschaffung in Kommunen. In Proceedings of the Wer Zahlt Bestimmt die Musik, Web-Seminar of the EnergieAgentur, NRW and Prosperkolleg, Online, 25 March 2021.

42. Besch, A. Vergaberecht und Nachhaltigkeit. 2020. Available online: http://www.nachhaltige-beschaffung.info/DE/ VergaberechtundNachhaltigkeit/neuesvergaberecht_node.html (accessed on 27 September 2021). 
43. Witzel, A. The Problem-centered Interview. Forum Qualitative Sozialforschung / Forum: Qualitative Social Research. Qual. Res. Natl. Discip. Methodical Empir. Ex. 2000, 1, 22. [CrossRef]

44. Merten, K. Inhaltsanalyse: Einführung in Theorie, Methode und Praxis; Westdeutscher Verlag: Opladen, Germany, 1983.

45. Mayring, P. Qualitative Inhaltsanalyse. In Qualitative Forschung in der Psychologie, Grundfragen, Verfahrensweisen, Anwendungsfelder; Jüttemann, G., Ed.; Beltz: Weinheim, Germany, 1985; pp. 187-211.

46. European Union. Directive 2014/24/EU of the European Parlament and of the Council on Public Procurement and Repealing Directive 2004/18/EC. 2014. Available online: https:/ / eur-lex.europa.eu/legal-content/EN/TXT/HTML/?uri=CELEX:32014L0 $024 \&$ from $=$ DE (accessed on 1 November 2021).

47. Forum Vergabe. Anhang XIV zu RL 2014/24/EU: Dienstleistungen nach Artikel 74. 2016. Available online: http://www. forum-vergabe.de/fileadmin/user_upload/Gesetzestexte/2016.05_ANHANG_XIV_RL_2014-24-EU_A5.pdf (accessed on 29 October 2021).

48. Niese, N.; Pieper, C.; Arora, A.; Xie, A. The Case for a Circular Economy in Electric Vehicle Batteries. 2020. Available online: https: / / www.bcg.com/publications/2020/case-for-circular-economy-in-electric-vehicle-batteries (accessed on 4 November 2021).

49. Qiao, D.; Wang, G.; Gao, T.; Wen, B.; Dai, T. Potential impact of the end-of-life batteries recycling of electric vehicles on lithium demand in China: 2010-2050. Sci. Total Environ. 2021, 764, 142835. [CrossRef]

50. Businesswire. Global Bio-Based Polyurethane Market Report 2021: Increasing Product Demand from the Automotive Industry-Forecast to 2028. ResearchAndMarkets.com. 2021. Available online: https://www.businesswire.com/news/home/20 211103005954/en/Global-Bio-based-Polyurethane-Market-Report-2021-Increasing-Product-Demand-from-the-AutomotiveIndustry---Forecast-to-2028---ResearchAndMarkets.com (accessed on 4 November 2021).

51. Vreugdenhil, H.; Taljaard, S.; Slinger, J.H. Pilot projects and their diffusion: A case study of integrated coastal management in South Africa. Int. J. Sustain. Dev. 2012, 15, 148-172. [CrossRef]

52. $320^{\circ}$ Ein Reifen, der aus Recyclingmaterial Besteht und CO2 Absorbiert. 2021. Available online: https://320grad.de/ein-reifender-aus-recyclingmaterial-besteht-und-co2-absorbiert/ (accessed on 3 February 2020).

53. Sönnichsen, S.D.; Clement, J. Review of green and sustainable public procurement: Towards circular public procurement. J. Clean. Prod. 2020, 245, 118901. [CrossRef] 